Atmos. Chem. Phys., 10, 4867-4877, 2010

www.atmos-chem-phys.net/10/4867/2010/

doi:10.5194/acp-10-4867-2010

(C) Author(s) 2010. CC Attribution 3.0 License.

\title{
Atmospheric wet deposition of mercury and other trace elements in Pensacola, Florida
}

\author{
W. M. Landing ${ }^{1}$, J. M. Caffrey ${ }^{2}$, S. D. Nolek ${ }^{3}$, K. J. Gosnell ${ }^{4}$, and W. C. Parker ${ }^{5}$ \\ ${ }^{1}$ Department of Earth, Ocean, and Atmospheric Science, Florida State University, Tallahassee, FL 32306-4320, USA \\ ${ }^{2}$ Center for Environmental Diagnostics and Bioremediation, University of West Florida, Pensacola, FL 32514, USA \\ ${ }^{3}$ Dynamac Corporation, Kennedy Space Center, FL 32899, USA \\ ${ }^{4}$ Marine Sciences Program, University of Connecticut, Groton, CT 06340, USA \\ ${ }^{5}$ Department of Earth, Ocean, and Atmospheric Science, Florida State University, Tallahassee, FL 32306-4100, USA
}

Received: 30 November 2009 - Published in Atmos. Chem. Phys. Discuss.: 21 December 2009

Revised: 7 May 2010 - Accepted: 18 May 2010 - Published: 26 May 2010

\begin{abstract}
In an effort to understand and quantify the impact of local, regional, and far-distant atmospheric mercury sources to rainfall mercury deposition in the Pensacola, Florida watershed, a program of event-based rainfall sampling was started in late 2004. Modified Aerochem-Metrics wet/dry rainfall samplers were deployed at three sites in the region around the Crist coal-fired power plant and eventbased samples were collected continuously for three years. Samples were analyzed for total $\mathrm{Hg}$ and a suite of trace elements including $\mathrm{Al}, \mathrm{As}, \mathrm{Ba}, \mathrm{Bi}, \mathrm{Cd}, \mathrm{Ce}, \mathrm{Co}, \mathrm{Cr}, \mathrm{Cs}, \mathrm{Cu}, \mathrm{Fe}$, $\mathrm{Ga}, \mathrm{La}, \mathrm{Li}, \mathrm{Mg}, \mathrm{Mn}, \mathrm{Na}, \mathrm{Nb}, \mathrm{Ni}, \mathrm{P}, \mathrm{Pb}, \mathrm{Sb}, \mathrm{Se}, \mathrm{Si}, \mathrm{Sn}, \mathrm{Sr}$, $\mathrm{Th}, \mathrm{U}, \mathrm{V}$, and Zn. Nutrients (ammonia and nitrate) and major anions (chloride and sulfate) were also measured on each sample. Multivariate statistical methods were used to sort these tracers into factors that represent potential source categories contributing to the rainfall chemistry. $\mathrm{As}, \mathrm{Hg}, \mathrm{Sb}, \mathrm{Se}$, $\mathrm{Sn}$, and non sea-salt sulfate were all significantly correlated $(R>0.6)$ with one factor which we interpret as an anthropogenic source term reflecting input from coal combustion throughout the southeastern US. Using ratios of total $\mathrm{Hg}$ to volatile elements, we estimate that $22-33 \%$ of the rainfall $\mathrm{Hg}$ results from coal combustion in the southeastern US with the majority coming from the global background.
\end{abstract}

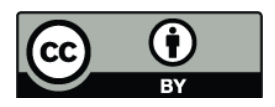

Correspondence to: W. M. Landing (wlanding@fsu.edu)

\section{Introduction}

Atmospheric mercury deposition is a cause for great concern for human health in the United States as well as all other parts of the world due to atmospheric mercury incorporation as methyl mercury into fish. Current emissions to the atmosphere are estimated to be more than three times the preindustrial amount. Anthropogenic $\mathrm{Hg}$ released to the atmosphere is estimated to be $3.4 \times 10^{9} \mathrm{~g} / \mathrm{yr}$ (Selin et al., 2008 and references therein). Gaseous elemental mercury (GEM) is believed to have a lifetime of 0.5 to 2 years in the troposphere before it is oxidized and washed out of the atmosphere. Atmospheric emissions of GEM from industrial point-sources are therefore widely dispersed throughout the atmosphere before finally becoming oxidized to reactive gaseous mercury (RGM), and some conversions to aerosol mercury ( $\mathrm{HgP})$, after which they will deposit quickly through wet and dry deposition. The impact of long-range atmospheric transport and deposition of anthropogenic mercury in Greenland was reported nearly 40 years ago by Weiss et al. (1971). The increase in the global background of atmospheric mercury due to anthropogenic emissions was reviewed by Fitzgerald et al. (1998) and a decade later by Selin (2009). More recently, the impacts of local, regional, and distant anthropogenic mercury emission sources were discussed for Korea (Nguyen et al., 2010) and southern China (Fu et al., 2010). The use of global atmospheric models to evaluate the impacts from long-range transport of anthropogenic mercury is now commonplace (e.g. Lin et al., 2010 and references therein).

Published by Copernicus Publications on behalf of the European Geosciences Union. 
Several studies have been conducted in the state of Florida in an effort to determine the influence of regional and global sources of $\mathrm{Hg}$ to the watersheds but few have been conducted to determine the effects of known point-source emitters to the local watersheds. One such study was conducted in 1993 over a three-week period in Broward County, Florida (Dvonch et al., 1998). Daily rain event samples were collected and analyzed for total $\mathrm{Hg}$ and other trace elements. The samples collected nearest the point source had elevated $\mathrm{Hg}$ levels as compared to a control site, suggesting the importance of a local point-source. Using data from the Florida Atmospheric Mercury Study (FAMS), Guentzel et al. (2001) concluded that local sources of atmospheric $\mathrm{Hg}$ could only account for about $30-46 \%$ of the rainfall deposition of $\mathrm{Hg}$ to the Florida Everglades during the same period.

Our study was originally commissioned to evaluate the impact of one particular coal-fired power plant (Gulf Power Company's Crist plant) on rainfall $\mathrm{Hg}$ deposition in Pensacola. By sampling individual rain events at three sites over three full years we have identified some important characteristics of the $\mathrm{Hg}$ and other chemical tracer concentrations from local and regional emissions, and from long-range transport from far-distant sources (the "global background"). These characteristics include seasonal variation and uniformity of deposition to the watershed. In addition to $\mathrm{Hg}$ concentrations in each rain sample, we analyzed a suite of trace elements including the alkali metals and alkaline earth elements, the transition metals, and the rare earth elements. By using multi-element factor analysis we were able to identify at least three factors that can explain greater than $67 \%$ of the variance in the data. Those factors include mineral dust, seasalt aerosols, and an anthropogenic factor that explains much of the variance for $\mathrm{As}, \mathrm{Hg}, \mathrm{Sb}, \mathrm{Se}, \mathrm{Sn}$, and non sea-salt sulfate $\left(\mathrm{nss}-\mathrm{SO}_{4}\right)$; species that are commonly associated with coal combustion. Our data suggest that coal combustion in the southeastern US pollutes the regional airshed with these volatile tracers, but that the majority of the rainfall $\mathrm{Hg}$ appears to be derived from the "global background" of RGM and $\mathrm{HgP}$ produced via GEM oxidation.

\section{Study area}

This research was conducted as part of the Partnership for Environmental Research and Community Health (PERCH) in order to quantify the atmospheric deposition (in rainfall) of $\mathrm{Hg}$ and trace elements to the Pensacola Bay watershed. There are numerous potential local, regional, and distant sources for $\mathrm{Hg}$ and other trace elements in rainfall. It was shown by $\mathrm{Fu}$ and Winchester (1994) that the entire southeastern US airshed is affected by $\mathrm{NO}_{\mathrm{x}}$ emissions, primarily from coal-fired power plants. Thus we would expect to find $\mathrm{Hg}$ and trace elements associated with coal combustion in Pensacola rainfall. $\mathrm{NO}_{\mathrm{x}}$ and $\mathrm{SO}_{2}$ emissions are dominated by power generation, although $\mathrm{NO}_{\mathrm{x}}$ emissions are also the result of motor vehicle activity in the region. The Crist plant in Pensacola is estimated to release on the order of $200 \mathrm{lbs}$ of $\mathrm{Hg}$ per year to the atmosphere, with about $25 \%$ as reactive gaseous mercury (RGM) that should exhibit some local impact. Other sources of $\mathrm{Hg}$ to the Pensacola Bay watershed include automobiles, a medical waste incinerator, a paper mill, chemical plants and other manufacturing companies. The paper mill burns coal and releases about $1.9 \mathrm{lbs} /$ year; the other sources combined account for less than $0.06 \mathrm{lbs} / \mathrm{year}$ (T. Rogers, Florida Department of Environmental Protection, personal communication, 2010). There are other sources of atmospheric $\mathrm{Hg}$ in Alabama and Georgia (and throughout the southeastern US), mostly the result of coal combustion for electricity generation. According to the 2005 EPA air emissions inventory, two nearby counties in Alabama (Mobile and Escambia) were responsible for 780 and $880 \mathrm{lbs}$. of atmospheric $\mathrm{Hg}$ emission.

\subsection{Sampling sites and rain sampling equipment}

Rain collectors were installed at three sites between November and December 2004 (Fig. 1) and maintained through December 2007 for event based collection of rain samples using AerochemMetrics model 301 and equivalent Loda model 2001 rain samplers (Fig. 2a). The first collection site is at the Florida Department of Environmental Protection (FDEP) site at the Ellyson Industrial Park located off Scenic Highway in Pensacola $\left(30.5256^{\circ} \mathrm{N}, 87.2033^{\circ} \mathrm{W}\right)$. This site was chosen for its close proximity (about $4.7 \mathrm{~km}$ southeast) to the Crist coal fired power plant. The sampler is set on an open raised platform on fenced FDEP property. Event rain collection began at this site in November 2004. The second site is located on the fenced property of Pace Water Systems in Santa Rosa County $\left(30.6023^{\circ} \mathrm{N}, 87.19126 \circ \mathrm{W}\right)$. The sampler is set in a remote open area near a small wetland pond. Access to this site is limited to employees of Pace Water Systems and those with permission to enter the site. This site is approximately $5.5 \mathrm{~km}$ east-northeast of the power plant. Event rain collection began in December 2004 at this site. The third collection site is about $24.2 \mathrm{~km}$ northwest of the power plant on private property in the city of Molino $\left(30.6903^{\circ} \mathrm{N}, 87.4103^{\circ} \mathrm{W}\right)$. This site is remote with very little human disturbance. The sampler is set in an open field with no obstructions within at least 50 feet. Event rain sample collection at this site began in mid-December 2004. This site was chosen because it is often upwind of the Crist power plant, and is impacted by air masses coming out of the southeastern US.

A Plexiglas "splash guard" was attached to the leading edge of the retractable roofs to minimize rain splash contamination of the sample bottles when the roof is retracting (Fig. 2a). The "wet" buckets were modified to hold 3 bottles with Teflon collars and $0.008 \mathrm{~m}^{2}$ polycarbonate funnels (Fig. 2b) as in the Florida Atmospheric Mercury Study (Landing et al., 1998). Duplicate 1.0 L FEP Teflon bottles for $\mathrm{Hg}$ and trace element analyses were deployed along with 
a single $1.0 \mathrm{~L}$ polyethylene bottle for $\mathrm{pH}$ and major ions analysis. About $10 \%$ of the deployments had a single Teflon bottle and duplicate polyethylene bottles for $\mathrm{pH}$ and major ions in order to acquire duplicate samples for QA/QC purposes. Results for $\mathrm{pH}$, major ions, and nutrients are reported in Caffrey et al. (2010). To avoid damage to the rain samplers, sampling was suspended from 9-26 July 2005 due to Hurricane Dennis. Rain samples were collected within $24 \mathrm{~h}$ of $0.5 \mathrm{~cm}$ rain events and shipped back to FSU for processing and multi-element analysis. The funnel/collar combination was removed from the receiving bottle, and the receiving bottles were capped, and replaced with freshly cleaned bottles. The funnel/collar combinations were changed every 6 months, or sooner if they appeared to have been soiled by insects, birds, or plant debris. This equipment replacement frequency was shown to be appropriate during the FAMS project (Landing et al., 1998).

\section{Analytical methods}

\subsection{Mercury analysis}

Rain samples (in FEP Teflon bottles) were acidified after return to the FSU clean lab to $0.045 \mathrm{M} \mathrm{HCl}$ plus $0.048 \mathrm{M} \mathrm{HNO}_{3}$, using ultra-pure acids (Optima, Fisher Scientific), then placed in a low wattage UV digestion box $\left(730 \mu w a t t s / \mathrm{cm}^{2} ; 254 \mathrm{~nm}\right)$ for at least $48 \mathrm{~h}$ to completely solubilize the collected $\mathrm{Hg}$ (Landing et al., 1998). FEP Teflon bottles are about $50 \%$ transparent to UVA radiation $(254 \mathrm{~nm})$ produced using low pressure $\mathrm{Hg}$ vapor lamps. The digested samples were analyzed by cold vapor atomic fluorescence spectroscopy (CVAFS) following EPA method 1631 using a Tekran 2600 Mercury Analyzer. We use ultra-pure $\mathrm{HCl}$ and $\mathrm{HNO}_{3}$ for sample acidification and UV digestion because the standard oxidant for total dissolved $\mathrm{Hg}$ analysis (bromine monochloride; $\mathrm{BrCl}$ ) is not clean enough for the other trace elements we wish to analyze. Landing et al. (1998) showed that the $\mathrm{HCl} / \mathrm{HNO}_{3} / \mathrm{UV}$ treatment is as effective as $\mathrm{BrCl}$ for the analysis of $100 \%$ of the total dissolved $\mathrm{Hg}$ from rain and freshwater samples.

\subsection{ICPMS analysis}

A multi-element analytical program was set up using a Thermo-Finnigan "Element-I" high-resolution magnetic sector ICP-MS. We analyzed for $\mathrm{Al}, \mathrm{Ba}, \mathrm{Bi}, \mathrm{Cd}, \mathrm{Ce}, \mathrm{Co}, \mathrm{Cr}$, Cs, $\mathrm{Cu}, \mathrm{Fe}, \mathrm{Ga}, \mathrm{La}, \mathrm{Li}, \mathrm{Mg}, \mathrm{Mn}, \mathrm{Na}, \mathrm{Nb}, \mathrm{Ni}, \mathrm{P}, \mathrm{Pb}, \mathrm{Sb}, \mathrm{Si}, \mathrm{Sr}$, Th, U, V, and Zn. An Agilent 7500cs quadrupole ICP-MS equipped with an octopole reaction-collision cell (ORC) was used to measure As, Se, and Sn. Helium gas was used in the ORC for the As and $\mathrm{Sn}$ analyses while $\mathrm{H}_{2}$ gas was used for the Se analyses. All analyses were conducted using external standard solutions (in the same $\mathrm{HCl}+\mathrm{HNO}_{3}$ matrix as the samples), and the analytical sensitivities were compared to spiked samples (standard additions) to confirm that there
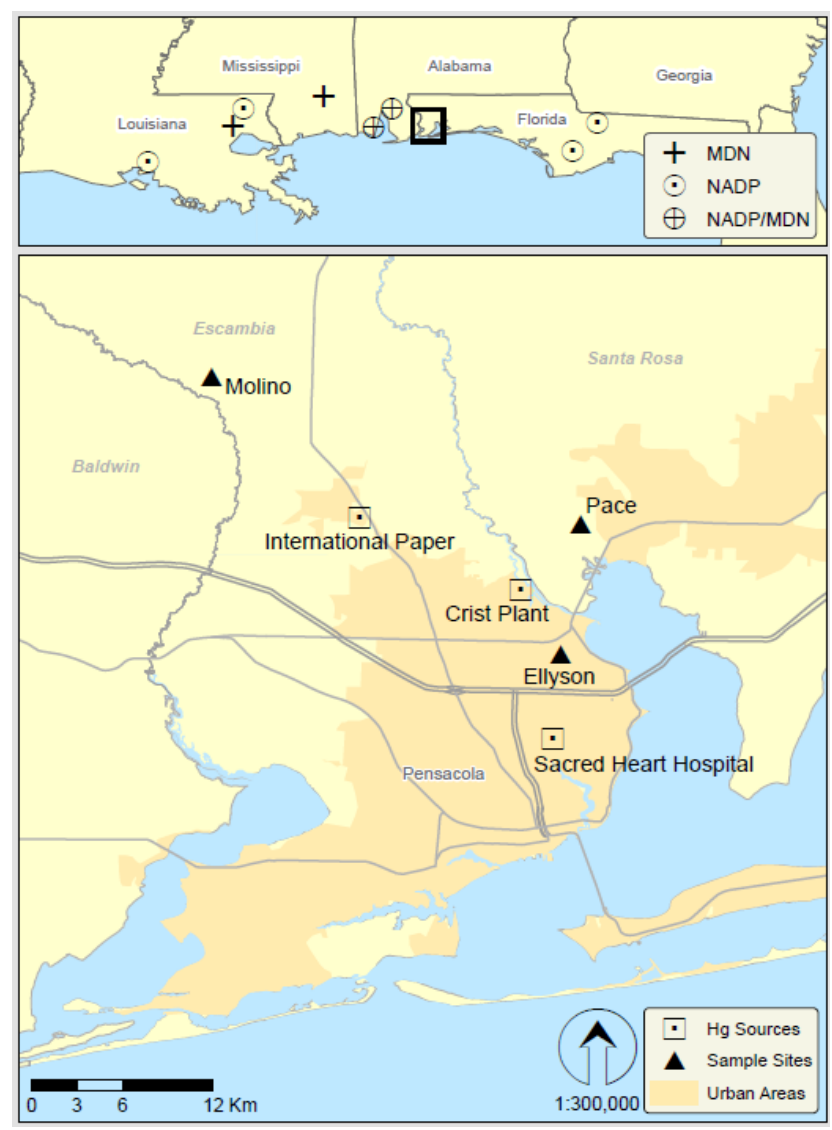

Fig. 1. Rainfall sampling sites and atmospheric $\mathrm{Hg}$ sources in the Pensacola, Florida area. NADP sites are part of the National Acid Deposition Program; MDN sites are part of the NADP Mercury Deposition Network.

was no signal suppression or enhancement due to slight matrix differences between samples and standards.

Analytical results from duplicate rain samples in the FEP Teflon bottles are shown in Fig. 3 for $\mathrm{Hg}$, As, Se, and Cr. When the concentrations are well above the method detection limits, one finds excellent agreement between the " $\mathrm{A}$ " and "B" duplicate samples, as is seen for $\mathrm{Hg}$, As, and Se. One sees greater scatter for $\mathrm{Cr}$ about a 1:1 line passing through the data, indicating that the concentrations are approaching the method detection limit (also seen for $\mathrm{Hf}, \mathrm{Ni}, \mathrm{Ta}$, and $\mathrm{Zr}$ ). Table 1 shows the reagent and sample processing blanks together with the minimum, maximum, median, and volume-weighted mean (VWM) concentrations for all elements used in further statistical analysis of the data. "Acid Matrix Blanks" refers to the ultrapure $0.045 \mathrm{M} \mathrm{HCl}$ plus $0.048 \mathrm{M} \mathrm{HNO}_{3}$ matrix used for all samples and standards. "Bottle Blanks" refers to a processing blank wherein after subsampling for trace element analyses, an FEP Teflon sample bottle was rinsed then filled with ultrapure deionized water and acidified to $0.045 \mathrm{M} \mathrm{HCl}$ plus $0.048 \mathrm{M} \mathrm{HNO}_{3}$. These bottles were UV oxidized then subsampled and analyzed 


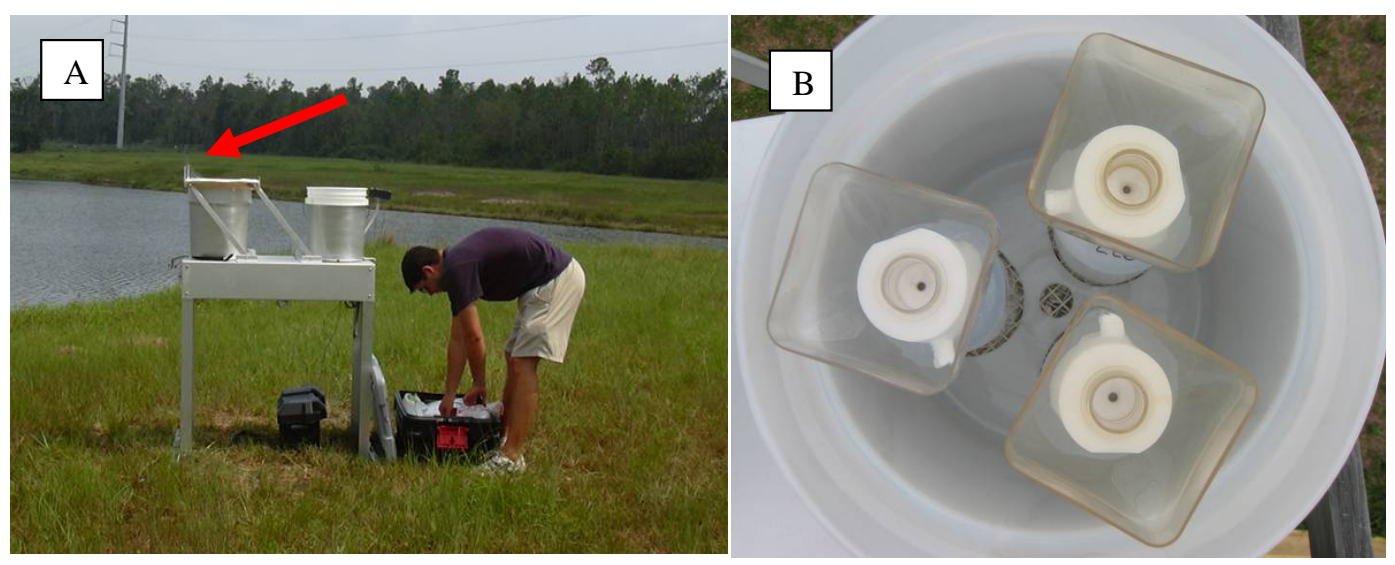

Fig. 2. (A) Automated rainfall collector with a $15 \mathrm{~cm}$ tall Plexiglas splash guard on the leading edge of the roof to avoid splash contamination during roof retraction (red arrow). (B) Modified receiving bucket with three nested receiving bottles connected to $0.008 \mathrm{~m}^{2}$ polycarbonate funnels using PTFE-Teflon collars.
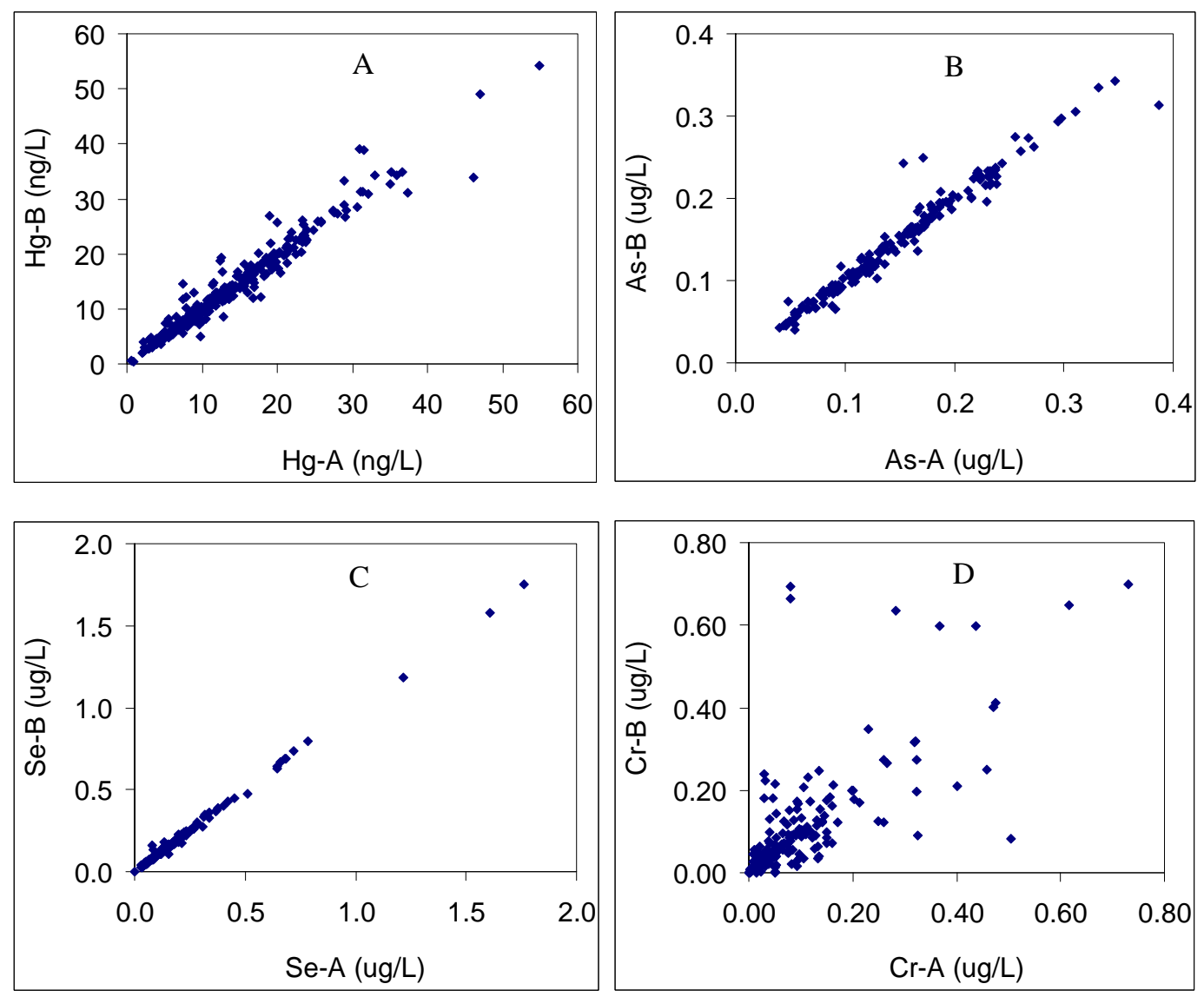

Fig. 3. Comparison of analyses of duplicate (A vs. B) rain samples. Mercury (A), arsenic (B), and selenium (C) all show excellent agreement with data well above the detection limits. Chromium (D) shows greater scatter due to concentrations closer to the detection limit. 
Table 1. Analytical information and descriptive statistics. See text for description of each column. VWM = volume weighted mean concentration for the three year period 2005-2007.

\begin{tabular}{|c|c|c|c|c|c|c|c|c|c|c|c|}
\hline \multirow[t]{2}{*}{ Element } & \multirow{2}{*}{$\begin{array}{l}\text { Concentration } \\
\text { Units }\end{array}$} & \multirow[t]{2}{*}{ Isotope } & \multirow[t]{2}{*}{ Resolution } & \multicolumn{2}{|c|}{ Acid Matrix Blanks } & \multicolumn{2}{|c|}{ Bottle Blanks } & \multicolumn{4}{|c|}{ Rain Samples } \\
\hline & & & & Mean & $1 \mathrm{SD}$ & Mean & $1 \mathrm{SD}$ & Minimum & Maximum & Median & VWM \\
\hline $\mathrm{Al}$ & $\mathrm{ppb}$ & 27 & Medium & 0.40 & 0.03 & 0.58 & 0.23 & 1.54 & 830 & 38.7 & 53.4 \\
\hline As & $\mathrm{ppb}$ & 75 & $\mathrm{ORC} / \mathrm{He}$ & 0.040 & 0.003 & 0.106 & 0.005 & 0.0440 & 0.610 & 0.162 & 0.194 \\
\hline $\mathrm{Ba}$ & ppt & $137 \& 138$ & Low & 3.0 & 1.0 & 4.0 & 2.0 & 21.2 & 10600 & 694 & 1000 \\
\hline $\mathrm{Bi}$ & ppt & 209 & Low & 0.30 & 0.20 & 0.40 & 0.20 & 0.0558 & 33.1 & 1.48 & 2.68 \\
\hline $\mathrm{Cd}$ & ppt & 111 & Low & 0.94 & 0.45 & 1.16 & 0.61 & 0.00107 & 230 & 3.73 & 7.34 \\
\hline $\mathrm{Ce}$ & ppt & 140 & Low & 0.22 & 0.11 & 0.60 & 0.50 & 2.33 & 1100 & 45.9 & 88.0 \\
\hline Co & ppb & 59 & Medium & 0.0007 & 0.0002 & 0.001 & 0.001 & 0.00062 & 0.561 & 0.0205 & 0.0298 \\
\hline $\mathrm{Cr}$ & ppb & 52 & Medium & 0.006 & 0.002 & 0.010 & 0.010 & 0.00107 & 3.40 & 0.075 & 0.099 \\
\hline Cs & ppt & 133 & Low & 0.3 & 0.2 & 0.3 & 0.2 & 0.149 & 42.4 & 3.23 & 4.02 \\
\hline $\mathrm{Cu}$ & ppt & $63 \& 65$ & Medium & 0.022 & 0.010 & 0.066 & 0.010 & 0.00869 & 4.61 & 0.242 & 0.313 \\
\hline $\mathrm{Fe}$ & ppb & 56 & High & 0.33 & 0.28 & 0.51 & 0.35 & 0.692 & 400 & 15.9 & 26.0 \\
\hline $\mathrm{Ga}$ & ppt & 69 & Low & 1.00 & 0.10 & 1.00 & 0.10 & 0.0146 & 250 & 31.4 & 36.7 \\
\hline $\mathrm{Hg}$ & ppt & Total & CVAFS & 0.55 & 0.09 & 0.66 & 0.18 & 2.87 & 58.3 & 15.1 & 17.3 \\
\hline $\mathrm{La}$ & ppt & 139 & Low & 0.41 & 0.11 & 0.76 & 0.43 & 2.01 & 470 & 28.4 & 47.6 \\
\hline $\mathrm{Li}$ & ppt & 7 & Medium & 4.72 & 2.42 & 11.01 & 3.00 & 2.02 & 470 & 48.7 & 59.3 \\
\hline $\mathrm{Mg}$ & ppt & 24 & Medium & 0.162 & 0.004 & 0.203 & 0.095 & 4.14 & 540 & 53.6 & 100 \\
\hline $\mathrm{Mn}$ & $\mathrm{ppb}$ & 55 & Medium & 0.002 & 0.001 & 0.004 & 0.001 & 0.0709 & 12.2 & 0.655 & 1.13 \\
\hline $\mathrm{Na}$ & $\mathrm{ppb}$ & 23 & Medium & 0.63 & 0.23 & 0.66 & 0.40 & 30.0 & 5840 & 681 & 985 \\
\hline $\mathrm{Nb}$ & ppt & 93 & Low & 0.30 & 0.30 & 0.80 & 0.30 & 0.112 & 42.9 & 2.02 & 2.58 \\
\hline $\mathrm{Ni}$ & $\mathrm{ppb}$ & 60 & Medium & 0.018 & 0.007 & 0.014 & 0.006 & 0.0060 & 15.5 & 0.247 & 0.374 \\
\hline $\mathrm{P}$ & ppb & 31 & Medium & 0.13 & 0.05 & 0.28 & 0.20 & 0.441 & 160 & 4.38 & 6.18 \\
\hline $\mathrm{Pb}$ & ppt & 208 & Low & 5.98 & 6.05 & 5.78 & 4.60 & 0.436 & 1970 & 226 & 306 \\
\hline $\mathrm{Sb}$ & ppt & $121 \& 123$ & Low & 0.40 & 0.30 & 0.50 & 0.30 & 3.86 & 180 & 37.2 & 48.3 \\
\hline $\mathrm{Se}$ & ppb & 78 & $\mathrm{ORC} / \mathrm{H}_{2}$ & 0.020 & 0.003 & 0.030 & 0.003 & 0.0320 & 1.88 & 0.137 & 0.257 \\
\hline $\mathrm{Si}$ & ppb & 28 & Medium & 5.0 & 3.0 & 6.0 & 3.0 & 0.855 & 1750 & 47.0 & 75.7 \\
\hline $\mathrm{Sn}$ & $\mathrm{ppb}$ & 120 & $\mathrm{ORC} / \mathrm{He}$ & 0.010 & 0.001 & 0.040 & 0.004 & 0.0194 & 0.334 & 0.056 & 0.066 \\
\hline $\mathrm{Sr}$ & ppt & 88 & Low & 4.0 & 1.4 & 8.0 & 4.0 & 46 & 6820 & 519 & 860 \\
\hline Th & ppt & 232 & Low & 0.1 & 0.1 & 0.1 & 0.1 & 0.301 & 130 & 4.72 & 7.95 \\
\hline $\mathrm{U}$ & ppt & 238 & Low & 0.1 & 0.1 & 0.1 & 0.1 & 0.0910 & 57.7 & 2.22 & 3.35 \\
\hline V & ppb & 51 & High & 0.023 & 0.004 & 0.025 & 0.007 & 0.00563 & 2.83 & 0.198 & 0.274 \\
\hline $\mathrm{Zn}$ & $\mathrm{ppb}$ & $66 \& 68$ & Medium & 0.084 & 0.007 & 0.088 & 0.045 & 0.0556 & 54.1 & 1.07 & 2.19 \\
\hline $\mathrm{NH}_{3}$ & $\mathrm{ppb}$ & & & & 20 & & & 6.53 & 1340 & 106 & 125 \\
\hline $\mathrm{NO}_{3}$ & ppb & & & & 67 & & & 114 & 4200 & 963 & 925 \\
\hline $\mathrm{Cl}$ & ppb & & & & 85 & & & 107 & 50200 & 1100 & 2300 \\
\hline $\mathrm{SO}_{4}$ & $\mathrm{ppb}$ & & & & 60 & & & 129 & 6740 & 1340 & 1530 \\
\hline nss-SO ${ }_{4}$ & $\mathrm{ppb}$ & & & & 60 & & & 1 & 6530 & 1120 & 1360 \\
\hline
\end{tabular}

identically to the samples, and these are the blanks that were subtracted from the sample data. In general, the Bottle Blanks were slightly higher and slightly less precise than the Acid Matrix Blanks. Using 3 SD as an estimate for the Method Limit of Detection (MLOD), the MLOD was less than $25 \%$ of the median concentrations for all elements with the exceptions of $\mathrm{Cr}(30 \%), \mathrm{Nb}(35 \%)$, and ammonia (48\%).

\subsection{Anions and nitrogen species}

Chloride, nitrate, and sulfate were analyzed using EPA Method 300.0 on a Dionex DX500 ion chromatograph. Ammonium was analyzed using the IonPac CS16 column and Dionex protocols (Application Note 141, http://www.dionex. com/en-us/webdocs/4211-AN141_V15.pdf). The blank precision for those analyses are also shown in Table 1. Non sea-salt sulfate (nss- $\mathrm{SO}_{4}$ ) was calculated by subtracting the sea-salt sulfate fraction (the Na concentration multiplied by the sulfate/ $\mathrm{Na}$ ratio in seawater), using the assumption that $100 \%$ of the $\mathrm{Na}$ comes from sea-salt aerosols. Using $\mathrm{Al}$ as a tracer for mineral dust, and the Na/Al ratio in the Earth's crust (0.339), we calculate that less than $2 \%$ of the $\mathrm{Na}$ in our samples results from mineral dust.

\section{Results}

A total of 225 separate rain events were sampled from 19 November 2004 through 2 January 2008. We observed generally higher rainfall amounts in the Spring 

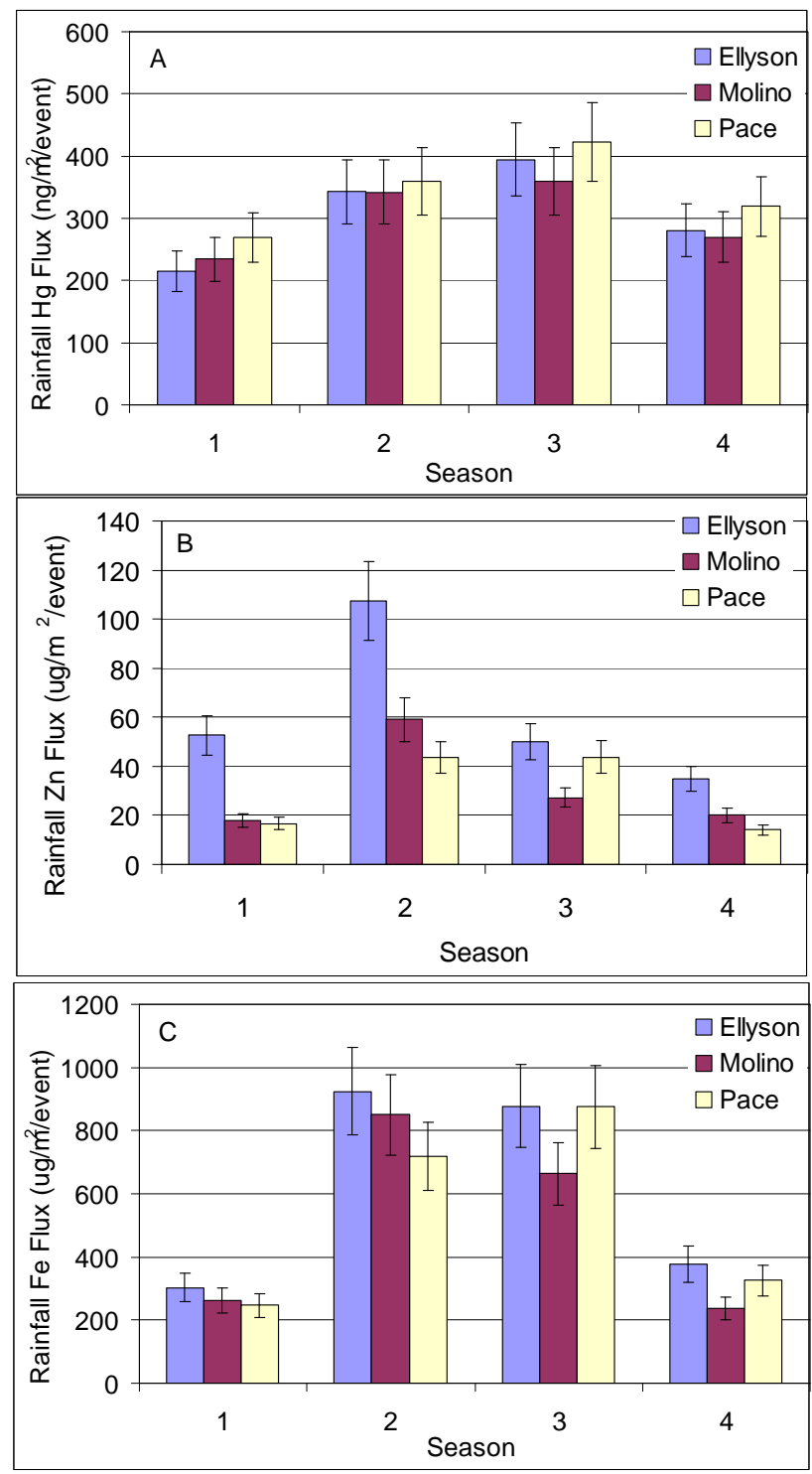

Fig. 4. Seasonal comparisons of rainfall fluxes at the three sampling sites in the Pensacola area for $\mathrm{Hg}(\mathbf{A}), \mathrm{Zn}(\mathbf{B})$, and $\mathrm{Fe}(\mathbf{C})$. Season 1: December-February. Season 2: March-May. Season 3: JuneAugust. Season 4: September-November. Error bars are \pm 1 SD of the 3-year mean values.

(March-May), although the annual amount of precipitation was similar at the three sites, and in each year of the study.

Seasonally aggregated rainfall fluxes for $\mathrm{Hg}, \mathrm{Zn}$, and $\mathrm{Fe}$ for the entire 3 year sampling period are shown for example in Fig. 4. While we see higher rainfall $\mathrm{Hg}$ fluxes in Spring and Summer (Fig. 4a), the Hg fluxes are comparable between the three sampling sites, despite the much closer proximity to the Crist power plant of the Ellyson site $(4.7 \mathrm{~km})$ relative to the Molino site $(24.2 \mathrm{~km})$. Rainfall $\mathrm{Hg}$ fluxes were also similar to rainfall $\mathrm{Hg}$ fluxes at nearby sites that are part of the NADP/Mercury Deposition Network (see Caffrey et al., 2010).
Rainfall fluxes of $\mathrm{Zn}$ were higher at the Ellyson site, which is likely from $\mathrm{Zn}$ enriched aerosols due to its heavily urbanized location and the amount of vehicular traffic on the surrounding interstate (I-10) and highways (Fig. 4b). The rainfall fluxes of $\mathrm{Fe}$ are shown as an example of the impact of mineral dust aerosols (Fig. 4c). During the Spring and Summer months, mineral dust from arid regions in Africa is uplifted into the dry Saharan Air Layer and makes its way within 7-10 days across the North Atlantic where it impacts Florida and the eastern Gulf of Mexico (e.g. Prospero, 1999). During those months, we see higher rainfall fluxes of $\mathrm{Fe}$ (and other trace elements associated with mineral dust; $\mathrm{Si}, \mathrm{Al}, \mathrm{Mn}$, $\mathrm{Cs}, \mathrm{La}, \mathrm{Ce}-$ and the other rare earth elements $-\mathrm{Th}$, and $\mathrm{U}$ ). We also see no dramatic differences between the three sites, indicating that the mineral dust is more likely the result of long-range transport rather than locally-generated soil dust from agricultural practices. A very similar pattern of summertime mineral dust deposition was reported for wet deposition rain samples from the Florida Everglades (Landing et al., 1995) and more recently by Trapp et al. (2009) at the RSMAS/UM facility on Virginia Key, Florida.

There are significant inter-element relationships in our dataset that appear to reflect source categories for various aerosol types. Supporting the previous conclusions regarding mineral dust transport and deposition, Fig. 5a shows the very strong correlation between the wet deposition of $\mathrm{Fe}$ and $\mathrm{Al}$ $\left(R^{2}=0.93\right)$. The slope of the regression line $(0.56 \pm 0.01 \mathrm{~g} / \mathrm{g})$ is within the range of $\mathrm{Fe} / \mathrm{Al}$ mass ratios reported for the Earth's crust $(0.63 \pm 0.10 \mathrm{~g} / \mathrm{g})$. Correlation coefficients $(R)$ greater than 0.7 were also found between $\mathrm{Al}$ and $\mathrm{Ba}, \mathrm{Ce}, \mathrm{Cs}$, $\mathrm{La}, \mathrm{Mn}, \mathrm{Nb}, \mathrm{Si}$, Th, and $\mathrm{U}$. Figure $5 \mathrm{~b}$ shows the strong correlation between $\mathrm{Sr}$ and $\mathrm{Mg}\left(R^{2}=0.85\right)$. The slope of the regression line $(0.0062 \pm 0.0002)$ is very close to the seawater ratio of 0.0061 . Correlation coefficients greater than 0.7 were found between $\mathrm{Na}, \mathrm{Mg}$, and $\mathrm{Sr}$, as these are all indicators of the input of sea-salt aerosols.

Multi-element data of this type are often evaluated using multi-variate statistical methods such as factor analysis or positive matrix factorization. We used SPSS Statistics 17.0 to analyze the data using factor analysis (with Varimax rotation). Varimax rotation was used because it maximizes the variance of the squared factor loadings. It tends to produce a simple structure in the retained factors such that each chemical species is associated with one or a few factors, thus the interpretation of the factors is more straightforward. Since Varimax is an orthogonal method, the factors remain uncorrelated. We used the flux data set rather than the concentration data set since small volume rain events often have high concentrations of many elements and this can skew the analysis. Because factor analysis assumes normally distributed data, the flux data set was log-transformed then tested for normality using the Kolmogorov-Smirnov Statistic with Lilliefor's Significance (SPSS 17.0). The $p$ values are reported in Table 2, showing that only the Cd flux data set $(p=0.006)$ was significantly different from a normal distribution. As 
Table 2. Varimax rotated factor matrix of the log-transformed rainfall flux data using SPSS Statistics 17.0. The Kolmogorov-Smirnov statistic with Lilliefors' Significance was used to test for normality in the log-transformed flux data. None of the data distributions, except $\mathrm{Cd}(p=0.006)$, were significantly different from normal distributions. Factor loadings are equivalent to $R$ correlation coefficients. $R$ values greater than 0.6 are highlighted.

\begin{tabular}{|c|c|c|c|c|}
\hline & $\begin{array}{c}\mathrm{K} / \mathrm{S} \\
p\end{array}$ & $\begin{array}{l}\text { Factor } 1 \\
\text { Loading }\end{array}$ & $\begin{array}{l}\text { Factor } 2 \\
\text { Loading }\end{array}$ & $\begin{array}{l}\text { Factor } 3 \\
\text { Loading }\end{array}$ \\
\hline $\log \mathrm{Hg}$ & 0.711 & 0.268 & 0.703 & 0.128 \\
\hline Log As & 0.945 & 0.089 & 0.833 & 0.283 \\
\hline $\log \mathrm{Se}$ & 0.906 & 0.129 & 0.805 & 0.262 \\
\hline $\log \mathrm{Sb}$ & 0.489 & 0.389 & 0.807 & 0.193 \\
\hline $\log \mathrm{Sn}$ & 0.835 & 0.047 & 0.714 & 0.252 \\
\hline $\log \mathrm{Na}$ & 0.283 & 0.059 & 0.408 & 0.731 \\
\hline $\log \mathrm{NH}_{3}$ & 0.638 & 0.374 & 0.743 & 0.215 \\
\hline $\log \mathrm{NO}_{3}$ & 0.765 & 0.444 & 0.637 & 0.127 \\
\hline $\log \mathrm{Cl}$ & 0.950 & -0.097 & 0.403 & 0.609 \\
\hline $\log \mathrm{SO}_{4}$ & 0.920 & 0.152 & 0.729 & 0.332 \\
\hline Log nss $\mathrm{SO}_{4}$ & 0.200 & 0.053 & 0.676 & 0.124 \\
\hline $\log \mathrm{Al}$ & 0.766 & 0.939 & 0.132 & 0.013 \\
\hline $\log \mathrm{Ba}$ & 0.939 & 0.650 & 0.357 & 0.141 \\
\hline $\log \mathrm{Bi}$ & 0.986 & 0.502 & 0.614 & 0.140 \\
\hline $\log C d$ & 0.006 & 0.248 & 0.247 & 0.311 \\
\hline $\log \mathrm{Ce}$ & 0.966 & 0.942 & 0.268 & 0.078 \\
\hline Log Co & 0.720 & 0.550 & 0.252 & 0.175 \\
\hline $\log \mathrm{Cr}$ & 0.986 & 0.601 & 0.126 & 0.116 \\
\hline $\log \mathrm{Cs}$ & 0.838 & 0.876 & 0.275 & 0.163 \\
\hline $\log \mathrm{Cu}$ & 0.984 & 0.455 & 0.561 & 0.190 \\
\hline $\log \mathrm{Fe}$ & 0.370 & 0.956 & 0.161 & 0.048 \\
\hline $\log \mathrm{Ga}$ & 0.138 & 0.375 & 0.345 & 0.349 \\
\hline $\log \mathrm{La}$ & 0.951 & 0.920 & 0.324 & 0.122 \\
\hline $\log \mathrm{Li}$ & 0.183 & 0.530 & 0.360 & 0.285 \\
\hline $\log \mathrm{Mg}$ & 0.853 & 0.235 & 0.256 & 0.924 \\
\hline $\log M n$ & 0.817 & 0.857 & 0.375 & 0.184 \\
\hline $\log \mathrm{Nb}$ & 0.892 & 0.693 & 0.299 & 0.216 \\
\hline $\log \mathrm{Ni}$ & 0.214 & 0.157 & 0.343 & 0.223 \\
\hline $\log P$ & 0.921 & 0.472 & 0.477 & 0.186 \\
\hline $\log \mathrm{Pb}$ & 0.705 & 0.501 & 0.586 & 0.261 \\
\hline $\log \mathrm{Si}$ & 0.752 & 0.879 & -0.040 & 0.128 \\
\hline $\log \mathrm{Sr}$ & 0.912 & 0.459 & 0.335 & 0.808 \\
\hline $\log \mathrm{Th}$ & 0.928 & 0.943 & 0.079 & 0.038 \\
\hline $\log U$ & 0.946 & 0.836 & 0.357 & 0.270 \\
\hline $\log \mathrm{V}$ & 0.800 & 0.396 & 0.439 & 0.350 \\
\hline $\log \mathrm{Zn}$ & 0.520 & 0.390 & 0.540 & 0.215 \\
\hline
\end{tabular}

will be discussed below, exclusion of the Cd data from the factor analysis did not alter our conclusions.

The analysis showed 6 factors with eigenvalues greater than 1.0. The first three factors accounted for $67 \%$ of the variance in the data, while the next three factors accounted
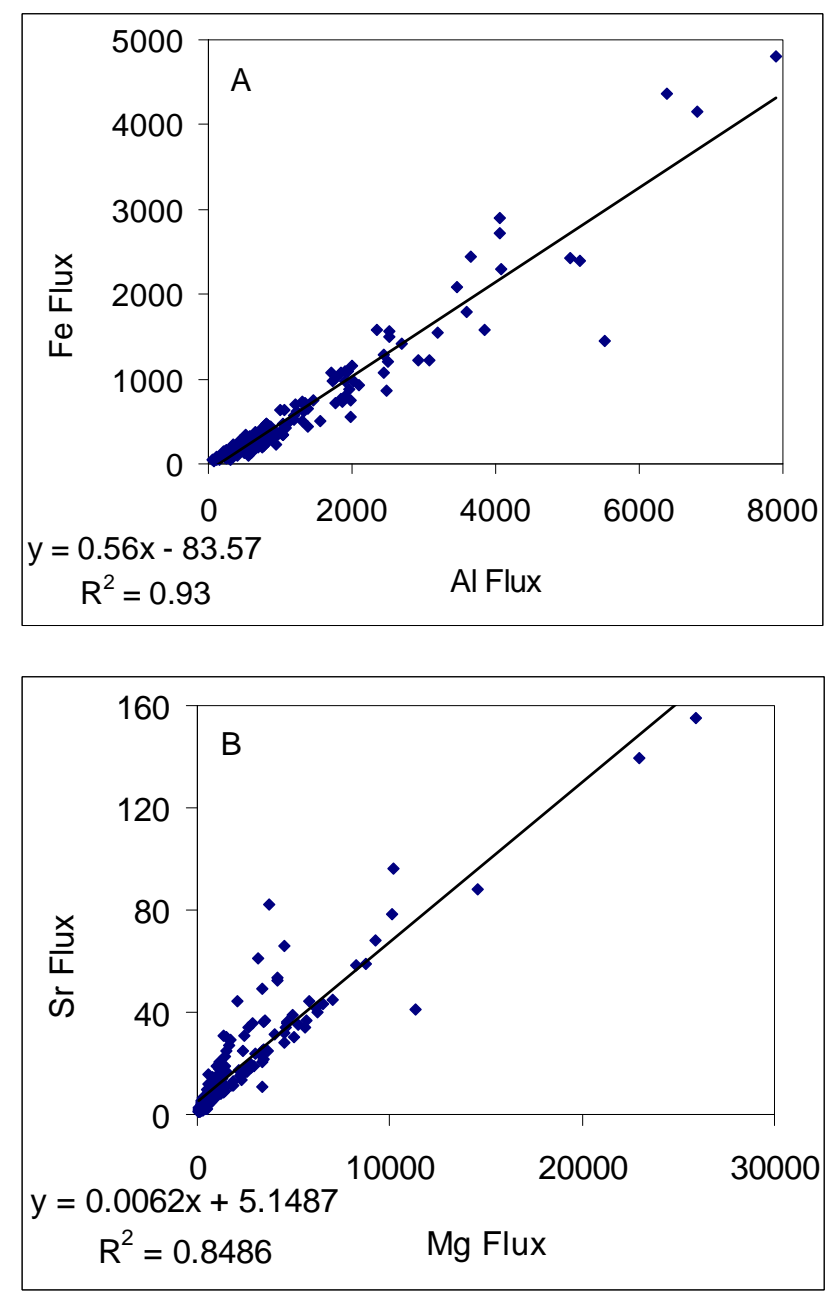

Fig. 5. Scatter plots of the rainfall flux data for $\mathrm{Fe}$ vs. Al, reflecting the contribution from mineral dust (A), and $\mathrm{Sr}$ vs. $\mathrm{Mg}$, reflecting the contribution from sea salt aerosols (B). Correlation coefficients $\left(R^{2}\right)$ are from linear regression analysis. All flux units are $\mu \mathrm{g} / \mathrm{m}^{2}$ per rain event.

for less than 5\% (each) of the variance. We re-ran the analysis while reducing the number of factors from 6 , to 5 , to 4 , and finally to 3 (Table 2). The same associations between the various chemical tracers and these first three factors were observed in each of these analyses. Since we are employing factor analysis as an exploratory, rather than a confirmatory technique, the choice of how many factors to retain is less critical. Our final selection is based on a number of considerations: eigenvalues, scree plots, broken stick modeling, percentage of variance and interpretability. Because there is no universally accepted method of making this decision and our primary interest is in characterizing potential sources, interpretability is considered most important. We recognize that the number of factors retained will influence the outcome of the Varimax rotation. The results shown are those deemed most representative and informative from several analyses 

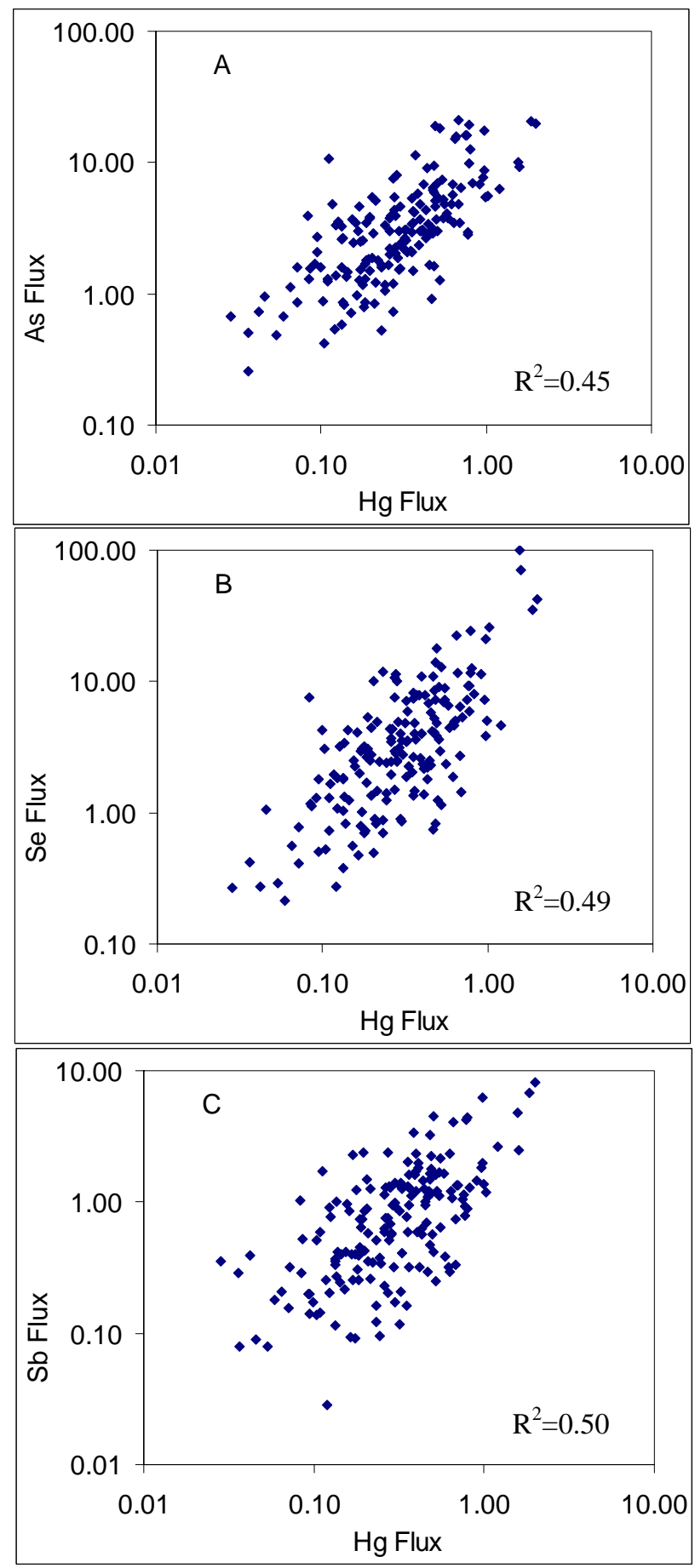

Fig. 6. Scatter plots of the rainfall flux data for As vs. $\mathrm{Hg}(\mathbf{A}), \mathrm{Se}$ vs. $\mathrm{Hg}(\mathbf{B})$, and $\mathrm{Sb}$ vs. $\mathrm{Hg}(\mathbf{C})$. Correlation coefficients $\left(R^{2}\right)$ are from linear regression analysis. All flux units are $\mu \mathrm{g} / \mathrm{m}^{2}$ per rain event. Log axes are used to display the full range of the data.

retaining and rotating different numbers of factors, as determined by application of all the criteria listed above.

Factor 1 accounts for $32 \%$ of the variance and is clearly related to the mineral dust flux, since we see high $R$ values (greater than 0.6) for $\mathrm{Al}, \mathrm{Ba}, \mathrm{Ce}, \mathrm{Cs}, \mathrm{Fe}, \mathrm{La}, \mathrm{Mn}, \mathrm{Nb}, \mathrm{Si}$, Th, and U. Factor 2 accounts for $24 \%$ of the variance and appears to be related to anthropogenic pollution and shows high $R$ values for $\mathrm{Hg}, \mathrm{As}, \mathrm{Se}, \mathrm{Sb}, \mathrm{Sn}$, and $\mathrm{nss}^{-\mathrm{SO}_{4}}$. We interpret this component to reflect input from atmospheric emissions during coal combustion (to be discussed later). By calculating the apparent $\mathrm{Hg}$ fluxes associated with Factor 2 for each rain event and summing these estimated fluxes over the entire 3-year period, we can estimate that $43 \pm 10 \%$ of the $\mathrm{Hg}$ flux was associated with this factor. Factor 3 accounts for $11 \%$ of the variance and obviously reflects the input of seasalt aerosols, with high correlations between $\mathrm{Na}, \mathrm{Mg}$, and Sr. Removing Cd from the factor analysis (because of the lack of normality in the log-transformed flux data set) did not alter these results. Removing $\mathrm{Cr}$ from the factor analysis (due to the lower duplicate sample precision) also did not alter the results. In support of the factor analysis results and interpretation, Fig. 6 shows scatter plots of the fluxes of As vs. $\mathrm{Hg}, \mathrm{Se}$ vs. $\mathrm{Hg}$, and $\mathrm{Sb}$ vs. $\mathrm{Hg}$. Figure 7 shows scatter plots of the fluxes of $\mathrm{Sn}$ vs. $\mathrm{Hg}$ and nss-SO $\mathrm{SO}_{4}$ vs. $\mathrm{Hg}$. All of the linear regressions between the fluxes of these tracers and $\mathrm{Hg}$ fluxes are highly significant $(p<0.001)$.

\section{Discussion}

Because of the negative human health effects from $\mathrm{Hg}$ exposure, the various states and the US EPA are all working on reducing anthropogenic $\mathrm{Hg}$ emissions within the US with the goal of reducing atmospheric $\mathrm{Hg}$ deposition. A recent analysis of the global $\mathrm{Hg}$ cycle (Selin et al., 2008) suggests however that only $20 \%$ of the $\mathrm{Hg}$ deposition over the USA is due to North American (primarily USA) industrial emissions, while $31 \%$ is due to sources outside the USA. They also concluded that $32 \%$ of the $\mathrm{Hg}$ deposition was due to the natural $\mathrm{Hg}$ cycle and that $16 \%$ was the result of legacy anthropogenic $\mathrm{Hg}$ accumulated in soils and the oceans. The recent REMSAD analysis conducted by the EPA (REMSAD, 2008) reaches a similar conclusion, that greater than $50 \%$ of the atmospheric $\mathrm{Hg}$ deposition across the USA is due to $\mathrm{Hg}$ emissions outside the USA. The data from the Florida Atmospheric Mercury Study in the mid-1990s, the more recent NADP/MDN data, and the recent modeling studies all suggest that there is a large long-range transport (or "global background") component to rainfall $\mathrm{Hg}$ deposition in Florida and along the coast of the northeastern Gulf of Mexico, especially during the summer months. Guentzel et al. (2001) concluded that less than $30-46 \%$ of the rainfall $\mathrm{Hg}$ in the Florida Everglades was due to local and regional emissions, and that over 50\% was due to long-range transport from distant sources that have merged into what is referred to as "the global background". Guentzel et al. (2001) further showed that their data were consistent with $\mathrm{Hg}$ transport (and oxidation to RGM and $\mathrm{HgP}$ ) in the northeast trade winds, which sweep across southern Florida and up into the northeastern 
Gulf of Mexico during the period from June through September. They suggested that these air masses were efficiently scrubbed by the tall convective thunderstorms common to this region because both the concentrations and fluxes of rainfall $\mathrm{Hg}$ increased during the summer months. Our observation of higher than average rainfall $\mathrm{Hg}$ deposition in Spring and Summer (Fig. 4a) suggests that long-range transport of $\mathrm{Hg}$ may dominate rainfall $\mathrm{Hg}$ deposition during those months in our study area as well.

The relatively long residence time of gaseous elemental mercury (GEM) in the troposphere ( $\sim 6-24$ months) allows GEM to be transported very long distances before it is ultimately oxidized to reactive gaseous mercury (RGM), some of which becomes associated with aerosols. The aerosol $\mathrm{Hg}$ and RGM from the "global background", as well as from regional (within 1,000 km) and local (within $100 \mathrm{~km}$ ) emission sources, have residence times on the order of days and are quickly removed by wet and dry deposition. Other primary aerosol, secondary aerosol, and reactive gaseous pollutants should also deposit relatively quickly, thus any given rain event will include contributions from these other pollutant tracers mostly from local and regional sources while $\mathrm{Hg}$ contributions would come from local, regional, and far-distant sources (i.e. the global background).

We can use our data to estimate the fraction of rainfall $\mathrm{Hg}$ that results from various anthropogenic activities, namely coal combustion. For this estimation, we assume that rain samples from our study include chemical tracers such as volatile elements (As, $\mathrm{Sb}, \mathrm{Se}, \mathrm{Sn}$, and nss-SO ${ }_{4}$ ) that will primarily reflect the contributions of those tracers from local and regional coal combustion. This assumption is supported by the $2005 \mathrm{EPA} \mathrm{Hg} \mathrm{emissions} \mathrm{inventory,} \mathrm{which} \mathrm{shows} \mathrm{that}$ we have very little metal ore smelting in the southeastern US that would also contribute to volatile element emissions. This inventory also reports that $\mathrm{Hg}$ emissions from Florida and the surrounding five states (Mississippi, Tennessee, Alabama, Georgia, and South Carolina) average 36-41\% RGM (oxidized $\mathrm{Hg}$ ) and $<10 \%$ particulate $\mathrm{Hg}$. Our rain samples should therefore contain aerosol and reactive $\mathrm{Hg}$ from local and regional sources, but could be dominated at times by RGM and $\mathrm{HgP}$ produced from the relatively slow oxidation of GEM derived from the global background (Selin et al., 2008; REMSAD, 2008). Thus, we would expect to find higher $\mathrm{Hg} /$ volatile element ratios in rain samples when the contribution of $\mathrm{Hg}$ from the global background is greater. Lower $\mathrm{Hg} /$ volatile element ratios would be expected when the contribution from local plus regional coal combustion dominates. In our samples, we found the lowest $\mathrm{Hg} / \mathrm{As}, \mathrm{Hg} / \mathrm{Sb}, \mathrm{Hg} / \mathrm{Se}, \mathrm{Hg} / \mathrm{Sn}$ and $\mathrm{Hg} / \mathrm{nss}^{-} \mathrm{SO}_{4}$ ratios in the November-March period, when transport of "background" $\mathrm{Hg}$ associated with the northeast trade winds would be at its minimum and when continental air masses (winter cold fronts) carrying volatile elements emitted from local and regional coal combustion frequently sweep across the region.
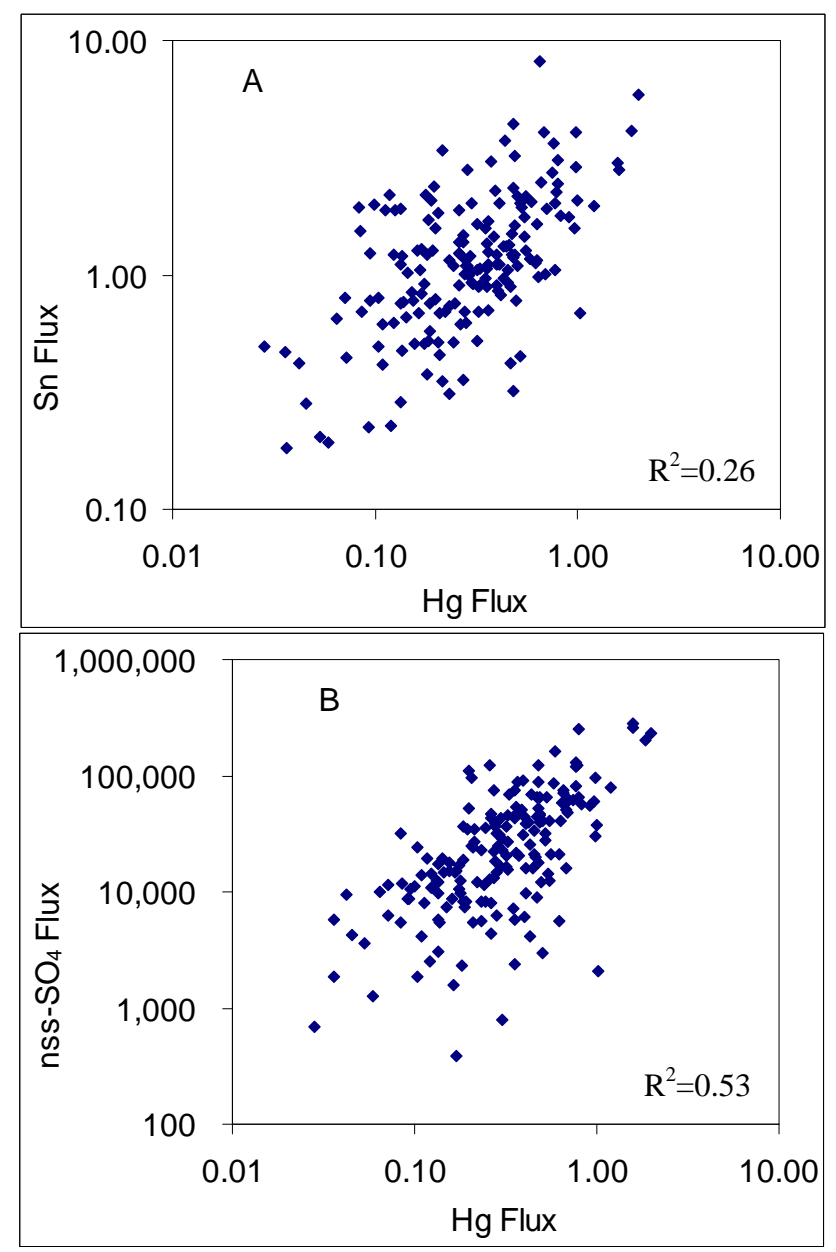

Fig. 7. Scatter plots of the rainfall deposition data for $\mathrm{Sn}$ vs. $\mathrm{Hg}$ (A), and nss- $\mathrm{SO}_{4}$ vs. $\mathrm{Hg}(\mathbf{B})$. Correlation coefficients $\left(\mathrm{R}^{2}\right)$ are from linear regression analysis. All flux units are $\mu \mathrm{g} / \mathrm{m}^{2}$ per rain event. Log axes are used to display the full range of the data.

With these concepts in mind, we can use Eq. (1) to estimate the fraction of rainfall $\mathrm{Hg}$ that might be due to local and regional emissions from coal combustion:

$\% \mathrm{Hg}$ from coal $=$

Annual VE deposition $\times(\mathrm{Hg} / \mathrm{VE})$ minimum

$$
\text { Annual } \mathrm{Hg} \text { deposition }
$$

When using this equation, we assume that $100 \%$ of the deposition of the volatile elements $\mathrm{As}, \mathrm{Sb}, \mathrm{Se}, \mathrm{Sn}$, and nss$\mathrm{SO}_{4}$ (Annual VE deposition) comes from local plus regional coal combustion, and that the lowest $\mathrm{Hg}$ /volatile ratios $((\mathrm{Hg} / \mathrm{VE})$ minimum) represent the impact of this source term on our rain sample chemistry. The Annual VE deposition term is perhaps slightly overestimated since there must surely be other sources of volatile elements in our study area. The $(\mathrm{Hg} / \mathrm{VE})$ minimum ratios may also be overestimated since there will surely be contributions of "background" $\mathrm{Hg}$, however small, even during the winter months. However, this 
Table 3. Minimum $\mathrm{Hg} /$ volatile element mass ratios used with Eq. (1) to estimate the fraction of rainfall $\mathrm{Hg}$ due to coal combustion in the southeastern US.

\begin{tabular}{lrc}
\hline Volatile Tracer & Minimum Hg/VE ratio & $\begin{array}{c}\% \mathrm{Hg} \text { from Coal } \\
\text { Combustion }\end{array}$ \\
\hline $\mathrm{As}$ & $0.028 \pm 0.008(\mathrm{~g} / \mathrm{g})$ & $31 \pm 9$ \\
$\mathrm{Sb}$ & $96 \pm 21(\mathrm{~g} / \mathrm{g})$ & $27 \pm 6$ \\
$\mathrm{Se}$ & $22 \pm 5(\mathrm{~g} / \mathrm{g})$ & $33 \pm 8$ \\
$\mathrm{Sn}$ & $58 \pm 8(\mathrm{~g} / \mathrm{g})$ & $22 \pm 3$ \\
$\mathrm{nss}-\mathrm{SO}_{4}$ & $3.1 \pm 0.9(\mu \mathrm{g} / \mathrm{g})$ & $31 \pm 9$ \\
\hline
\end{tabular}

particular overestimation is partly cancelled by the fact that the VE denominator in these $\mathrm{Hg} / \mathrm{VE}$ ratios includes some input of volatile elements from sources other than coal combustion. Correcting the $\mathrm{Hg}$ and volatile element fluxes for the contribution from mineral dust does not make a significant difference since that contribution is less than $1.9 \%$ for these elements (i.e. they are all greater than $98 \%$ "excess").

The average of the ten lowest $\mathrm{Hg} /$ volatile ratios was used to constrain the (Hg/VE)minimum value, and the Annual VE and Annual $\mathrm{Hg}$ deposition values were calculated from our data. Table 3 shows the results of these calculations, which suggest that from $22-33 \%$ of the rainfall $\mathrm{Hg}$ deposition at our sites in the Pensacola region can be attributed to local and regional coal combustion. These estimates are consistent with the REMSAD modeling results (using the $2001 \mathrm{EPA} \mathrm{Hg}$ emissions inventory) which suggested that $22 \%$ of the total atmospheric (wet plus dry) $\mathrm{Hg}$ deposition in the Pensacola area was due to local and regional sources, with $78 \%$ coming from the global background (D. Atkinson, US EPA, personal communication, 2010). These estimates are somewhat lower than, but not inconsistent with, the factor analysis results where we estimated that $43 \pm 10 \%$ of the rainfall $\mathrm{Hg}$ deposition was associated with the factor we believe reflects emissions from local and regional coal combustion (Factor 2, Table 2).

In conclusion, our data support a conceptual model that long-range transport and slow oxidation of gaseous elemental $\mathrm{Hg}$ are responsible for the majority of the rainfall deposition of $\mathrm{Hg}$ in the Pensacola region, and that local and regional coal combustion contribute a smaller fraction. We cannot identify any one particular emissions source with our data analysis, however we believe we have been able to identify at least one anthropogenic source category for rainfall $\mathrm{Hg}$ via its statistically significant associations with a set of other volatile chemical tracers.

We are currently investigating the relationships between meteorological conditions (air-mass trajectories and storm characteristics) and our rainfall tracer data. This will be the subject of future publications.
Acknowledgements. This study was a component of the "Assessment of Environmental Pollution and Community Health in Northwest Florida", supported by a subcontract to Florida State University under the US EPA Cooperative Agreement award X-9745502 to the University of West Florida (Project Director: K. Ranga Rao). The first 1.5 years of data were used in the MS Thesis of Sara Cleveland (Cleveland, 2006). We thank Fran Aftanas, Nathaniel Davila, Autumn Dunn, Elizabeth Gaige, Brad Kuykendall, Tanner Martin, Melissa Overton, and Pam Vaughan for their assistance in field collections. We thank Nishanth Krishnamurthy, Jan Macauley, Jeremy Bosso and the Wetland Research Laboratory for laboratory analyses. The Florida Department of Environmental Protection, Pace Water Systems, and Carol Hatcher provided access to sampling sites. We thank Jessie Brown for her assistance with the database development.

Edited by: K.-H. Kim

\section{References}

Caffrey, J. M., Landing, W. M., Nolek, S. D., Gosnell, K., Bagui, S. S., and Bagui, S. C.: Atmospheric deposition of mercury and major ions to the Pensacola Bay (Florida) watershed: spatial, seasonal, and inter-annual variability, Atmos. Chem. Phys. Discuss., 10, 4593-4616, doi:10.5194/acpd-10-4593-2010, 2010.

Chang, M. E., Baumann, K., Bostrom, A., and Russell, A.: PERCH Air Quality Study: an assessment of particulate matter, ozone, and air toxics in Escambia and Santa Rosa Counties, Final Report, Partnership for Community Health and Environmental Research, http://cure.eas.gatech.edu/ $\sim$ chang/perch/, last access: 25 May 2010, 2007.

Cleveland, S. D.: Atmospheric mercury input to the Pensacola Bay watershed, A thesis submitted to the Department of Oceanography in partial fulfillment of the requirements for the degree of Master's of Science Degree Awarded: Fall semester, 2006.

Dvonch, J. T., Graney, J. R., Marsik, F. J., Keeler, G. J., and Stevens, R. K.: An investigation of source-receptor relationships for mercury in south Florida using event precipitation data, Sci. Total Environ., 213, 95-108, 1998.

Fitzgerald, W. F., Engstrom, D. R., Mason, R. P., and Nater, E. A.: The case for atmospheric mercury contamination in remote areas, Environ. Sci. Technol., 32(1), 1-7, 1998.

Fu, J.-M. and Winchester, J. W.: Sources of nitrogen in three northern Florida watersheds: Mainly atmospheric deposition, Geochim. Cosmochim. Ac., 58, 1581-1590, 1994.

Fu, X. W., Feng, X., Dong, Z. Q., Yin, R. S., Wang, J. X., Yang, Z. R., and Zhang, H.: Atmospheric gaseous elemental mercury (GEM) concentrations and mercury depositions at a high-altitude mountain peak in south China, Atmos. Chem. Phys., 10, 24252437, doi:10.5194/acp-10-2425-2010, 2010.

Guentzel, J. L., Landing, W. M., Gill, G. A., and Pollman, C. D.: Processes influencing rainfall deposition of mercury in Florida: The FAMS Project (1992-1996), Environ. Sci. Technol., 35, 863-873, 2001.

Landing, W. M., Perry Jr., J. J., Guentzel, J. L., Gill, G. A., and Pollman, C. D.: Relationships between atmospheric deposition of trace elements, major ions and mercury in Florida: The FAMS project (1992-1993), Water Air Soil Poll., 80, 343-352, 1995. 
Landing, W. M., Guentzel, J. L., Gill, G. A., and Pollman, C. D.: Methods for measuring mercury in rainfall and aerosols in Florida, Atmos. Environ., 32(5), 909-918, 1998.

Lin, C.-J., Pan, L., Streets, D. G., Shetty, S. K., Jang, C., Feng, X., Chu, H.-W., and Ho, T. C.: Estimating mercury emission outflow from East Asia using CMAQ-Hg, Atmos. Chem. Phys., 10, 1853-1864, doi:10.5194/acp-10-1853-2010, 2010.

National Atmospheric Deposition Program (NRSP-3)/National Trends Network: NADP Program Office, Illinois State Water Survey, 2204 Griffith Drive, Champaign, IL 61820, 2009.

Nguyen, H. T., Kim, M. Y., and Kim, K. H.: The influence of longrange transport on atmospheric mercury on Jeju Island, Korea. Sci. Total Environ., 408(6), 1295-1307, 2010.

Prospero, J. M.: Long-term measurements of the transport of African mineral dust to the southeastern United States: implications for regional air quality, J. Geophys. Res.-Atmos., 104(D13), 15917-15927, 1999.
REMSAD: Model-Based Analysis And Tracking Of Airborne Mercury Emissions To Assist in Watershed Planning, 2008, Watershed Branch (4503-T), Office of Wetlands, Oceans, and Watersheds, US Environmental Protection Agency, 1200 Pennsylvania Avenue, NW Document posted at: http://www.epa. gov/owow/tmdl/pdf/final300report_10072008.pdf, last access: 25 May 2010.

Selin, N. E.: Global biogeochemical cycling of mercury: a review, Annu. Rev. Env. Resour., 34, 43-63, 2009.

Selin, N. E., Jacob, D. J., Yantosca, R. M., Strode, S., Jaegle, L., and Sunderland, E. M.: Global 3-D land-ocean-atmosphere model for mercury: Present-day versus preindustrial cycles and anthropogenic enrichment factors for deposition, Global Biogeochem. Cy., 22(2), GB2011, doi:10.1029/2007GB003040, 2008.

Trapp, J. M., Prospero, J. M., and Millero, F. J.: Temporal Variability of the Elemental Composition of African Dust Measured in Trade Wind Aerosols at Barbados and Miami, Mar. Chem., 120, 71-82, 2009.

Weiss, H. H., Koide, M., and Goldberg, E. D.: Mercury in a Greenland ice sheet - evidence of recent input by man, Science, 174, 692, 1971. 